\title{
Objectification of Losses in Accounting of Agricultural Organizations
}

\author{
Polikarpova E.P.* \\ Ryazan State Agrotechnological University Named after \\ P.A. Kostychev \\ Ryazan, Russia \\ Dikusar85@mail.ru
}

\author{
Mizikovskiy I.E. \\ Lobachevsky State University of Nizhny Novgorod \\ Nizhny Novgorod, Russia
}

\begin{abstract}
Currently available industry recommendations and scientific developments in the field of studying losses as an object of accounting from the point of view of the characteristics of agriculture are limited to the consideration of losses from the death of animals. The article clarifies the definition of losses in terms of production management and the construction of its accounting and information basis in this industry. Based on the industry-specific features of losses occurrence and their causes, a cycle-oriented approach to the systematization of losses in agricultural organizations is presented. A classification of losses of a long agricultural production cycle is proposed, an approach to the procedure for recognizing spoilt production is presented. The results obtained serve as a practical basis for organizing industry cost accounting for time efficient and relevant reporting information for production management needs.
\end{abstract}

Keywords - losses, losses accounting, features of agricultural production, long production cycle, spoilt production.

\section{INTRODUCTION}

Losses are a component of almost any economic activity, especially production. As an object of accounting, they reflect costs and losses. It is regulated by various regulatory documents, often industry recommendations for accounting the losses caused by spoilt production, shortages and losses from damage to valuables, other and extraordinary expenses. Losses are one of the key objects of research according to the concept of lean manufacturing.

The national standard of the Russian Federation "Lean Manufacturing" (GOST R 56020-2014) defines losses (waste, muda) as "any action at all levels of the organization, during the implementation of which resources are consumed, but no values are created" [1]. At the same time, the main types of losses are distinguished as overproduction, excess stocks, unnecessary transportation, delays (expectations, downtime), additional (unnecessary) processing, unnecessary movements, defects. Besides, additional types of losses can be determined, for example:

- variability (mura) - uneven work performance, fluctuations in demand, supply, instability of product characteristics;

- overload (muri) - excessive workload of equipment or operators that occurs when working at a higher speed or pace and with great effort over a long period of time compared to the design load;
- untapped staff potential - inability to use the talent and abilities of people to the full;

- transaction costs - costs associated with contractual activities, as well as management;

- insufficient value of products - non-compliance of products with expectations of the consumer and other interested parties.

Successful implementation of managerial functions to eliminate or reduce losses as much as possible involves their timely identification, calculation of the corresponding planned indicators, continuous monitoring of the production process, assessment of current production conditions, measurement of actual results, analysis of deviations, magnitude and causes of losses and determination of their nature and alternative opportunities of their elimination.

Undoubtedly, the place of accounting is in the lean manufacturing system as a source of providing management with an information base for calculating, analyzing and monitoring indicators that would allow timely tracking of losses [2].

The current level of development of information technology and machinery as well as results of scientific research makes it possible to measure losses and considered concepts of lean manufacturing. Various indicators are defined and analyzed that characterize losses due to overproduction, time losses due to waiting or unnecessary transportation and others. Lists of costs that form losses due to unnecessary processing steps, excess stock or production of defective products were determined [2]. Classifications of time types and methods are being developed that allow rationing of processing time, calculate losses and indicators that are part of the coefficient of overall economic efficiency [3].

However, when developing a detailed managerial approach to the classification of losses, the order of their measurement, control, analysis, elimination or reduction, one should rely on specific conditions for the implementation of activities, taking into account the specifics of production, primarily the industry. Environmental uncertainty distinguishes the characteristics of adaptive management of an agricultural enterprise [4-9].

The types of costs considered in the mentioned national standard are studied to a greater extent from the point of view of operating conditions different from the work of agricultural 
enterprises. For example, one of the stages of lean manufacturing is the "on time" method, which implies the abandonment of any insurance stocks that is not feasible in agriculture due to seasonal character, climate and weather conditions dependence that necessitate stocks of products and raw materials. It is obvious that in this case it is necessary to optimize storage conditions, the duration and size of the required reserves, excluding losses from their impairment, including damage, as well as loss.

In addition, on the example of the desire to reduce or eliminate the stock of material resources in the warehouse, one can point out the possible big risks for the manufacturer, which cause other losses - delays or defects. The situation under consideration implies slow delivery of raw materials or its unsatisfactory quality characteristics. The use of these raw materials can provoke a decrease in the expected quality of the products (defects). Failure to use it as well as slow delivery when the absence of stock in the warehouse can lead to downtime in the production process, sometimes accompanied by very serious consequences for the enterprise.

The lean manufacturing concept pays considerable attention to long-term partnerships with suppliers as a condition for continuous improvement and reduction of losses in the supply chain. However, long-term relationships, obviously, do not exclude the risks of the losses in question, which, in turn, are quite large when the economic activity of the enterprise is established before the long-term partnership is achieved. Due to the peculiarities of agricultural production, when the absence of material resources, losses caused by suppliers can have fatal consequences like reduction in yields, loss of livestock productivity or livestock population, etc.

The order to identify losses is of paramount importance. The duration of the production cycle and the unevenness of the processes necessitate an increase in pace and effort, for example, during harvesting. At the same time, the ambiguity of weather conditions mediates the inaccuracy of the calculated load. Therefore, this type of losses, to be exact their causes, can take place only when justifying other losses due to related reasons, for example, breakdown of the harvester as a result of low technical equipment during the harvest season.

For the same reasons, it is doubtful that overproduction and downtime, being typical losses for industry, correspond to agricultural peculiarities.

The studied production conditions determine the need to increase its volumes, which often acts as an indicator of improving the quality of production, as well as the need to provide initial distribution channels (for whole milk - by all means) and (or) conditions for long-term storage of products (for example, grain crops).

As for agriculture, based on understanding of downtime in many other sectors of the economy, it turns out that production equipment and machinery are not used for a larger period of the year. They are idle. However, this is due to the need to provide separate periods of intensive work and cannot be considered in relation to losses. If there were downtime as a result of a violation of the technological process, it justifies losses due to related causes. For example, it can be spoilage of raw grain caused by characteristic biological processes due to delayed post-harvest grain processing because of the idle grain elevator.

The features of agricultural production lead to the possibility of many different types of losses, some of which are caused by biological factors, the occurrence and consequences of which cannot be eliminated by the adoption and implementation of managerial decisions. For example, delaying the harvest, as is known, leads to losses in the gross output of grain from the field. However, if the deadlines are prolonged due to long and heavy rains, the consequences in the form of losses cannot be prevented.

It should be noted that modern advances in science and practice provide many ways to optimize the results of agricultural production, based on obtaining detailed information and biological characteristics of the production facility and using it to improve and maintain highly efficient materials, tools and technologies [10-16].

Worldwide research experience includes technologies using robots and "smart" machines, precision agriculture, alternative energy sources in the agricultural sector [17]. Modern technologies help to evaluate soil and atmospheric conditions and plant biomass, to control temperature, humidity, vibration and shock during transportation of crop products, as well as to monitor product demand and its condition on shelves of warehouses or inside refrigerators. The farm management platform can integrate systems of irrigation, weather data, seed preparation and agricultural machinery $[10,15]$.

The variety of opportunities offered imposes on management structures the responsibility to ensure the achievement of the maximum level of production results based on the search for alternative solutions, careful planning and development of adaptation measures to ensure products with the required characteristics.

\section{RESULTS AND DISCUSSION}

Accounting provides a significant informational basis for managerial actions. The variety of possible losses in the economy of a manufacturing organization in connection with peculiarities of the activity necessitates the objectification of losses in accounting records. Methodological material on loss accounting is presented in the authors' existing works and regulatory documents. It assumes the procedure for analytical and synthetic accounting of certain types of unproductive costs, product defects, shortages and losses from damage to values, natural loss, production waste, losses included in other expenses, as well as losses from emergency situations. However, the object in question has not been studied as a whole from the point of view of recognition in accounting.

To begin, it is necessary to refer to the definition of losses. Most explanatory dictionaries contain the following general interpretation of the term: "the fact or process of losing something or someone" [18] or "the amount of something unused for its intended purpose, uselessly wasted, lost and not saved" [19, 20] or "something that was not used for its intended purpose, was wasted, lost [21]. 
From the point of view of economic content, it is necessary to determine "something" from the indicated options of the definition for "loss". The required refinements can be found in the interpretation of the term in question according to accounting and economic dictionaries (encyclopedias): losses are a part of production resources (labor, means and objects of production) that was expended without return and without receiving products or was not used at all, that is, it didn't function or was idle [22-24]

It is obvious that the consumed (spent) production resources initially represent the costs of creating a labor product [25]. When the return on consumption is not followed, they go into the losses. The unequivocal lack of consumption (functioning) of resources does not initially imply a return on their availability (and not on use). It is the useless availability of funds in this case that forms losses. Valuation of costs for creation (acquisition or production) of these funds, as well as costs for creating a labor product without return, is a quantitative characteristic of losses (Fig. 1).

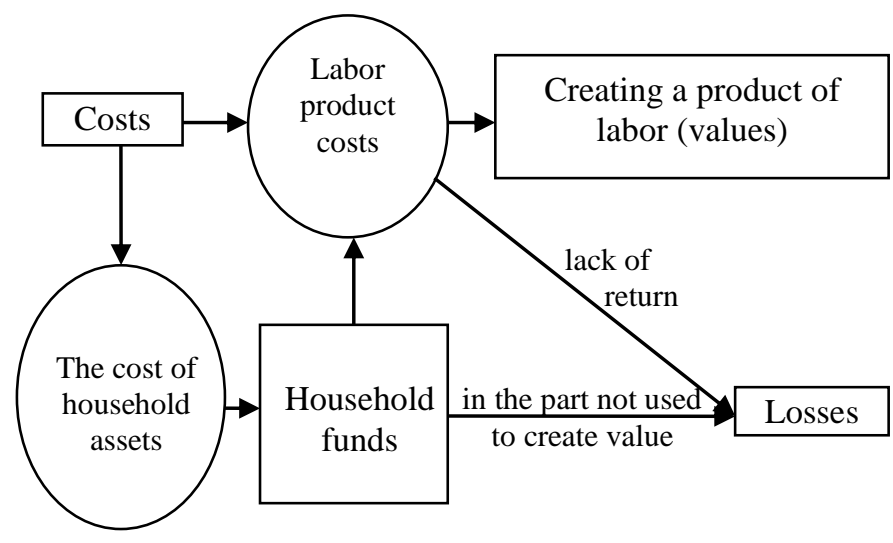

Fig. 1. The process of loss formation as an object of accounting

The previously viewed definition of losses according to the National Standard also involves the consumption of resources without return, that is, without creating value. In addition, the focus is on the reason for consumption or any action at all levels of the organization. In this case, actions are also assumed during the implementation of which funds were used to create subsequently unused (non-functioning) resources.

From the point of view of accounting, this clarification determines the basis for a business transaction, including recognition of losses, the fact of economic life, in this case an action involving the consumption of resources, consumption itself, as well as a statement of the absence of return (that is, the value is not created). In addition, for accounting purposes, documentary evidence of the relevant fact of economic life and the possibility of cost measurement of losses are necessary.

It is thought that the economic content of losses should not be limited directly to manufacturing of a product of labor.

It is necessary to take into account that the creation of value in entrepreneurial activity implies not only consumer value, but also exchange value, which manifests itself in the form of price [26], or in conjunction with the consumer one creates market value $[27,28]$. For example, for the purchase of materials that were not subsequently used in the production process and depreciated, financial resources were initially used. Moreover, these assets can be scrapped or sold at low prices, which indicates the presence of both consumer and exchange value. In this case, the loss will be considered the amount of money spent initially on the purchase of impaired unused materials in the future, with the exception of the amounts received from their sale. The production cycle in this case has not been started, and the possible occurrence of value has not been a product of labor.

Another example is bad debts receivable. Debts receivable is formed after the completion of the production cycle and sale of products - the result of already created value (for the consumer of the product of labor). It is embodied in exchange value and generates the company's income in the form of revenue. Its value forms the means in calculations, i.e. a resource that is not directly related to the production process but can cause cash inflow. If the corresponding rights of claim are not realized, the asset is not functioning and depreciated, and exchange value is lost, which is expressed in losses.

It is obvious that there are losses of the production cycle and related to it in ordinary activities of an economic entity.

In this regard, to objectify losses in accounting, a precise definition of them is proposed. Losses are a part of costs, as a result of which the corresponding return is not received, i.e. value is not created or lost. At the same time, the costs imply the consumption of any household assets and the absence of returns should be a documented fact of economic life.

The need to minimize or eliminate losses determines the primary task of organizing their accounting in any business according to the causes of losses. The root cause is always the efficiency and quality of the development and implementation of managerial decisions. Even when establishing the facts that cause the losses or indicating errors in actions of direct workers, their obvious reason is the lack of the manager's work. It can be the selection of unskilled personnel, the lack of proper vocational education and training, safety briefing or the overlook of factors, affecting the performance of the employee and others.

The organization of the analytical accounting of the causes of losses should provide for the detailing of the object and subject of specific works, the amount and time of work, labor costs, etc. Initially, the information structure is determined by management depending on the nature of the work, features of the production technology, expected and possible losses, planned values and other factors. As a result of it and according to the required information structure, forms of primary documents should be developed.

The object of losses for accounting may be specific assets embodying the corresponding costs (depreciated materials in the warehouse, costs of work in progress due to downtime and other production losses, debt receivable, stolen funds and others). In addition, a loss process should be distinguished to detail specific actions or events that lead to losses (the process of supplying raw materials according to contracts, specific production processes, transportation of materials, storage of products, the process of marketing products and others). It is 
important to establish the subjects of losses: specific employees, groups of employees and organization managers involved in a specific loss process.

The classification of losses and their causes, as well as the appropriate organization of their accounting at a particular enterprise, depends on characteristics of the economic activity, including industry-specific production.

Biological characteristics of agricultural production conditions complicate the work of managerial personnel in terms of planning accuracy, implementation of technological processes, work results, including forecasting, assessment and elimination or minimization of losses.

The variety of losses arising and their causes in organizations of the industry in question can be traced in materials of various scientific papers [29-33]. At the same time, the authors focus on the causes of losses inherent in agriculture during the implementation of a process.

The decline in product quality due to the selection of seeds and breeding stock of insufficiently high reproductions is considered, as well as losses from overuse of resources; crop losses from failure to comply with the systematic technological processes of grain production: failure to comply with crop rotation, sowing dates, suboptimal tillage, failure to control the production process (fertilizers, crop protection, etc.); the loss of technological operations due to low efficiency of agricultural machines, resources due to their low production and product losses due to the low technological quality of harvesting machines [30].

In the process of post-harvest grain processing dryers can not often cope with the entire flow of wet grain immediately, which leads to large losses of production and deterioration of its quality [34]. It is necessary to provide conditions for the protection of raw grain from spoilage before the dryer are released, cooling the grain mass by active ventilation [31]. These losses are an example of their occurrence in the final process of the grain production cycle, i.e. post-harvest grain processing.

It is necessary to consider separately the issues of waste in agricultural production, which have inherent biological characteristics. In crop production these are grain waste, tops, cabbage leaf, underdeveloped heads of cabbage, small and beaten potatoes, etc. In animal husbandry these are manure, molting wool and raw hair. Due to the possibility of further use for production needs or sales, they are often considered by-products. In any case, the costs associated with the production of these wastes cannot be attributed to losses, since their occurrence is caused by nature and ensures the production of the main products, as well as the process of their isolation from it. Thus, the formation of agricultural waste does not create losses. However, it can occur after the separation of waste (including by-products) in the cost of transportation, storage, compensation for environmental damage and others.

Features of agricultural activity form a point of view for considering the creation of value as one of the defining essence of losses different from many other sectors of the national economy.
Modern conditions of the domestic economy increase requirements for ensuring food security of the country. Improving the efficiency of agricultural production determines a significant part of the corresponding work, which initially determines the need, and therefore partly the value of labor products in the industry. The development of many methods for the utilization of agricultural waste at present [35-38] also determines the possible creation of value when manufacturing products.

As a result of the study of the industry-specific activities of agricultural organizations in terms of losses, one can denote their main types, which may serve as a basis for organizing their accounting:

- shortage and spoilage of reserves (derecognized immediately after identification) during storage and transportation (generally accepted synthetic and analytical accounts are used to account for identified shortages);

- depreciation of stocks due to physical and moral depreciation (when impairment is established, an estimated reserve is recognized according to certain criteria, followed by accounting as usual);

- natural loss during storage and transportation is accounted for as a shortage and then debited to the accounts of production costs;

- over-expenditure of resources is the unreasonable use of resources in excess of established standards (the formation of information is carried out using the wellknown method of normative accounting of costs with the appropriate organization of analytical accounting within and beyond norms);

- decrease in product quality in the process and result of production (it is necessary to organize analytical accounting in cost accounts);

- shortage of products (it is necessary to organize analytical accounting in cost accounts)

- death of animals, crops, etc. are taken into account depending on the following reasons: when identifying the perpetrators, they are debited to cost accounts; those caused by natural disasters (in the absence of insurance compensation) are debited to financial results and those in other cases are debited to cost accounts;

- depreciated debt receivable (an allowance with subsequent accounting in accordance with the established procedure is recognized;)

- fines, penalties, reimbursement of expenses to individuals and legal entities and similar payments are taken into account, as a rule, as part of other expenses. In addition, an estimated liability is calculated subject to the conditions.

It is necessary to note that the causes of losses can be both the impact of external factors: partners' failure to comply with the terms of the contract, worsening weather conditions, invasion of pests, etc., as well as internal ones: violation of 
storage conditions, incorrect development or violation of production technology, downtime, lack of efficiency management decisions and actions, equipment breakdown, etc.

Obviously, the causes of losses can often be eliminated both promptly and prevented in the future. However, among them there are reasons that are not amenable to managerial intervention (preventive and operational) and these are the uncontrolled impact of natural phenomena. The company must constantly carry out work on a detailed review of arising and expected losses.

As it is noted above, to control, evaluate, analyze and account for losses, the processes in which they occur should be distinguished. In agricultural organizations, the creation of a product of labor (the cultivation of many crops, the formation of offspring of animals, etc.) is often characterized by another distinctive feature of the industry - a long production cycle of several months [39]. Therefore, for a systematic presentation of the type, causes, sources and processes of loss formation, it is proposed to group them in relation to the implementation of the production cycle (Fig. 2).

A special type of production cycle loss is the loss of the amount of agricultural products received. Due to the influence of the reasons for their formation directly as a result of production technological processes, the inclusion of these losses in the composition of spoilt production is determined [30].

At the same time, the definition of spoilt production implies the presence of products, semi-finished products, parts, as well as works that either cannot be used for their intended purpose (the correction of which is technically impossible or economically impractical), or can be used for its intended purpose after correction [40]. Rejected labor products suggest that their quality does not meet established requirements [41].

At the same time, the yield of one hectare of the field, for example, is an indicator of the quality of production and the increase in live weight of animals when growing and fattening is an indicator of the intensity of production or the quality of the herd. Quantitative indicators are characteristics of the quality of production results.

Accounting for rejected technological work will make it possible to assess losses from defective goods, when there is a chance to evaluate the negative production results (low quality or shortage, as well as lack of products). The recognition of losses is also complicated by the fact that non-compliance of manufactured products with the established requirements for the expected volume of production is often a consequence of the failure to perform technological work, to have high-quality but late agricultural performance, including cases with unaccepted operational management decisions. In this situation, the only criterion for a rejected production result will be a quantitative indicator of the shortage of the product (for example, yield and increase in live weight) or the death of crops or animals.

Therefore, losses from defective goods should be determined systematically with a periodicity corresponding to stages of biological development of plants and animals in conjunction with the corresponding agricultural work. Periodicity is the prerogative of specialists or managers of the relevant industry and it depends on many factors: characteristics of expected products, expected and actual weather conditions, soil research results, a forecrop, a season, an animal health status and others. Obviously, analytical accounting of costs, including losses, must be organized accordingly, for example, on the interphase periods of the generative stage of wheat development and the agricultural work carried out.

\begin{tabular}{|c|c|c|}
\hline \multicolumn{3}{|c|}{ Losses in preparation for the production cycle } \\
\hline \multirow{2}{*}{$\begin{array}{l}\downarrow \\
\text { When planning technological } \\
\text { processes } \\
\text { (irrational management decisions } \\
\text { and errors in calculations lead to } \\
\text { losses in the future process work) }\end{array}$} & \multirow{2}{*}{\multicolumn{2}{|c|}{\begin{tabular}{|c|}
$\downarrow$ \\
When transporting and \\
storing reserves \\
(including natural loss, \\
shortage, spoilage, depreciation \\
of reserves, harm losses)
\end{tabular}}} \\
\hline & & \\
\hline \multicolumn{2}{|c|}{$\begin{array}{l}\text { When supplying resources } \\
\text { (including those from supply } \\
\text { disruption, poor quality of } \\
\text { resources, losses from } \\
\text { inefficient logistics, etc.) }\end{array}$} & $\begin{array}{l}\text { When preparatory } \\
\text { technological work } \\
\text { (including spoilt production, } \\
\text { etc.) }\end{array}$ \\
\hline
\end{tabular}

\begin{tabular}{|c|c|c|c|}
\hline \multicolumn{4}{|c|}{ Production cycle losses } \\
\hline & \multicolumn{2}{|c|}{7} & \\
\hline \multirow{7}{*}{$\begin{array}{l}\text { When direct } \\
\text { technological } \\
\text { work (including } \\
\text { spoilt production, } \\
\text { resource } \\
\text { overexpenditure, } \\
\text { harm losses, etc.) }\end{array}$} & \multicolumn{2}{|c|}{ When changing production } & \multirow{7}{*}{$\begin{array}{l}\text { When } \\
\text { transporting } \\
\text { reserves } \\
\text { (including } \\
\text { natural loss, } \\
\text { shortage, } \\
\text { spoilage of } \\
\text { reserves) }\end{array}$} \\
\hline & \multirow{6}{*}{$\begin{array}{c}\text { under } \\
\text { uncontrolled } \\
\text { exposure to } \\
\text { natural } \\
\text { phenomena }\end{array}$} & $-<$ & \\
\hline & & ahsence or & \\
\hline & & inoperative & \\
\hline & & proper & \\
\hline & & $\begin{array}{l}\text { adjustment of } \\
\text { production }\end{array}$ & \\
\hline & & technology & \\
\hline & \multirow{2}{*}{\multicolumn{2}{|c|}{$\begin{array}{l}\text { (shortage or decrease in product } \\
\text { quality (spoilt production), death of } \\
\text { crops and animals) }\end{array}$}} & \\
\hline & & & \\
\hline
\end{tabular}

Losses when using the results of the production cycle

\begin{tabular}{|c|c|}
\hline \multicolumn{1}{|c|}{$\begin{array}{c}\text { When ensuring the sale of } \\
\text { labor products (from irrational } \\
\text { marketing decisions, from breach } \\
\text { of contract, etc.) }\end{array}$} & $\begin{array}{l}\text { When transporting and storing } \\
\text { products (including natural loss, } \\
\text { shortage, spoilage, depreciation of } \\
\text { products, harm losses, etc.) }\end{array}$ \\
\hline
\end{tabular}

Fig. 2. Cycle-oriented approach to systematization of losses in agricultural organizations

Current recognition of spoilt production in livestock production limits to accounting for losses from the death of animals when raising and fattening. At the same time, the generally accepted procedure for writing off the carrying value of the fallen animal to production costs of live weight gain is considered incorrect.

To account for these losses, it is assumed economically feasible to write off the book value of animals to the account of losses and shortages from damage to values and the costs of raising or fattening a fallen animal, not previously written off when capitalizing on the increase in live weight, to account for 
spoilt production. To do this, appropriate analytical cost accounting should be organized by sex and age groups of animals, growing or fattening periods, responsibility centers, etc.

Similarly, in a case of a pregnant cow's death, losses also arise from the cost of producing the expected but not received offspring. Its inclusion in the spoilt production also requires the appropriate organization of analytical accounting [42]. The latter will also provide for accounting for other losses, including those due to barrenness of cows.

Thus, the losses associated with the expected results of the production cycle should be divided into losses from shortages and assets damage, defective products and defects in production technology caused by poor-quality or irrelevant technological works (Table 1).

TABLE I. CLASSIFICATION OF LOSSES OF A LONG AGRICULTURAL PRODUCTION CYCLE

\begin{tabular}{|c|c|}
\hline Type of loss & Concretization, examples \\
\hline \multicolumn{2}{|r|}{ in connection with specified allowances } \\
\hline $\begin{array}{l}\text { Resource over- } \\
\text { expenditure }\end{array}$ & $\begin{array}{l}\text { non-compliance with seeding rate, feeding standards, } \\
\text { agricultural work, etc. }\end{array}$ \\
\hline \multicolumn{2}{|c|}{ in connection with the expected results of the production processes } \\
\hline \multirow{3}{*}{$\begin{array}{l}\text { Defective goods } \\
\text { in manufacturing } \\
\text { technology }\end{array}$} & $\begin{array}{l}\text { correctable, as a result of which the expected } \\
\text { production result is not lost }\end{array}$ \\
\hline & incorrigible, leading to shortage of products \\
\hline & $\begin{array}{l}\text { failure to perform necessary work, as a result of } \\
\text { which the expected production result is lost }\end{array}$ \\
\hline Defective goods & $\begin{array}{l}\text { poor quality of products that can not be used for the } \\
\text { purpose specified }\end{array}$ \\
\hline $\begin{array}{l}\text { Shortage and } \\
\text { stocks damage }\end{array}$ & $\begin{array}{l}\text { losses and spoilage of raw materials during } \\
\text { transportation, shortage of work in progress as a } \\
\text { result of the death of crops and animals (caused by } \\
\text { the uncontrolled influence of natural phenomena), } \\
\text { etc. }\end{array}$ \\
\hline $\begin{array}{l}\text { Natural stock } \\
\text { decline }\end{array}$ & $\begin{array}{l}\text { as a result of wantage during transportation to and } \\
\text { from the field, etc. }\end{array}$ \\
\hline \multicolumn{2}{|c|}{ due to possible negative impact on third parties in production processes } \\
\hline Causing harm to & t, individua \\
\hline
\end{tabular}

At the same time, negative results of rejected agricultural work can be corrected by the implementation of appropriate costs. Otherwise they represent a decrease in the efficiency of production facilities and processes (for example, plant seedlings or cow productivity), and ultimately a shortage of products. The negative result is also caused by the lack of necessary work in the production technology (application of the required fertilizers, treatment of animals, etc.). Obviously, for the recognition and assessment of the considered losses from the shortage of products, managers specializing in the corresponding production area need to monitor and determine the results of technological processes at the end of each established period, corresponding to the stage of biological development of plants or animals in conjunction with the corresponding agricultural work. When signs of defective goods are identified in the technology, their causes and the share of the expected shortage of products should be determined and the rejected work performed should be specified.
However, among the reasons for the shortage of products of the production cycle, there is also death of crops, animals, etc., including cases caused by emergency situations. Depending on the volume and reasons for the specified shortage, the corresponding losses are either a defect in the production technology (as a result of rejected or unfulfilled work) or a shortage of work in progress.

Defective products are detected at the end of the production cycle (the product of labor cannot be used for its intended purpose because of its low quality). Recognition and assessment of losses from these defective products is carried out in the generally accepted manner.

For the most accurate recognition and accounting of losses associated with the expected results of production processes, it is necessary to establish that their causes belong either to the uncontrolled impact of natural phenomena, or to the consequences of the absence or inoperative proper adjustment of the production technology.

\section{CONCLUSION}

Features of the production activities of agricultural organizations necessitate the objectification of losses in accounting. The importance of conducting research in this direction is increasing due to the lack of substantive information and explanations in industry recommendations, as well as scientific developments.

As a result of studying the nature of losses from the point of view of agricultural production management and building its information basis - accounting, the definition of losses was clarified. Based on the industry-specific features of the occurrence of losses and their causes, a cycle-oriented approach to systematizing losses in agricultural organizations is presented. A classification of losses of a long agricultural production cycle is proposed and an approach to the procedure for recognition of defective goods is presented.

The results of objectification of losses in accounting serve a practical basis for organizing costs accounting for the industry, developing appropriate management documentation, building analytical accounting of losses of an economic entity for the operational generation of relevant reporting information.

\section{References}

[1] GOST R 56020-2014. Lean production. Fundamentals and vocabulary. Moscow: Standardinform, 2015.

[2] N.V. Parushina, N.A. Lytneva, "The system of indicators of costs and financial results in the concept of lean accounting and management", Fundam. Res., no. 12, pp. 202-206, 2016.

[3] I.G. Abramova, "The classification of expenses / losses work's time of technological equipment", Sci. of Europe, no. 39, pp. 28-36, 2019.

[4] A.S. Zavgorodnyaya, I.G. Shashkova, V.S. Konkina, L.V. Romanova, E.I. Mashkova, M.Yu. Pikushina, "Adaptive Management of the Agricultural Enterprise in the Conditions of Environmental Uncertainty", J. of Advan. Res. in Dynamical and Control Syst., no. 7 , (spec. iss.), pp. 2022-2031, 2018.

[5] C.S. Pletsch, C.E.F. Lavarda, L.F. Dallabona, G.R. de Oliveira, "Influência dos fatores contingenciais ambiente e estratégia nos sistemas 
de controle gerencial de uma cooperative agropecuária", Custos e @ gronegócio on line, vol. 15, no. 1, pp. 229-253, Jan-Mar 2019.

[6] N. Shakhramanyan, U.A. Schneider, B.A. Mccarl, "Pesticide and greenhouse gas externalities from US agriculture - the impact of their internalization and climate change", Climate Change Econ., vol. 04, no. 03, 2013.

[7] G. Cao, C. He, W. Xu, "Effect of weather on agricultural futures markets on the basis of DCCA cross-correlation coefficient analysis", Fluctuat. and Noise Letters, vol. 15, no. 02, 2016.

[8] R.R. Palatnik, F. Eboli, A. Ghermandi, I. Kan, M. Rapaport-Rom, M. Shechter, "Integration of general and partial equilibrium agricultural land-use transformation for the analysis of climate change in the Mediterranean", Climate Change Econ., vol. 02, no. 04, pp. 275-299, 2011

[9] X. Zhao, K.V. Calvin, M.A. Wise, "The critical role of conversion cost and comparative advantage in modeling agricultural land use change", Climate Change Econ., February 2020.

[10] O. Vyacheslavova, I. Parfenyeva, T. Levina, An. Klochkov, "Analysis of the data collection and processing system for assessing the actual reliability of domestic tractors exemplified by PJSC "Promtractor"', BIO Web of Conf. 2019, vol. 18, 2020.

[11] L.G. Kashirina, K.A. Ivanishchev, K.I. Romanov, "The quality of dairy products made from the milk of cows under the influence of vitamincontaining preparations", BIO Web of Conf. 2019, vol. 18, 2020.

[12] A.V. Shemyakin, S.N. Borychev, I.A. Uspenskiy, K.P. Andreev, V.V. Terentyev, "Improvement of the technological process of surface application of mineral fertilizers", BIO Web of Conf. 2019, vol. 18, 2020 .

[13] D.V. Vinogradov, M.Yu. Fedotova, M.M. Kryuchkov, N.V. Byshov, Ya.V. Kostin, R.N. Ushakov, "Influence of co-use of mineral, organomineral fertilizers and microbiological growth regulator on oats yield", Biosci. Biotechnol. Res. Communicat., spec. iss., vol 12, no. 5., pp. 299-307, 2019.

[14] S.D. Polischuk, G.I. Churilov, D.G. Churilov, S.N. Borychev, N.V. Byshov, D.V. Koloshein, O.V. Cherkasov, "Biologically active nanomaterials in production and storage of arable crops", Int. J. of Nanotechnol., vol. 16, iss. 1-3, pp. 133-146, 2019

[15] D. Vinogradov, E. Lupova, D. Khromtsev, V. Vasileva, "The infl uence of bio-stimulators on productivity of coriander in the non-chernozem zone of Russia”, Bulgarian J. of Agricult. Sci., vol. 24, no. 6, pp. 1078-1084, 2018.

[16] V.K. Chebotar, A.N. Zaplatkin, A.V. Shcherbakov, N.V. Mal'fanova, A.A. Startseva, Ya.V. Kostin, "Microbial preparations on the basis of endophytic and rhizobacteria to increase the productivity in vegetable crop and spring barley (Hordeum vulgare L.), and the mineral fertilizer use efficiency”, Agricult. Biolog., vol. 51, no. 3, pp. 335-342, 2016.

[17] B.A. Rounov, "The use of robotic tools in agriculture", Agricult. machinery and technol., no. 2, pp. 44-47, 2016.

[18] D. Thompson, The pocket Oxford dictionary of current English. Publisher Oxford: Clarendon, 1996.

[19] T.F. Efremova, The new dictionary of the Russian language. Interpretative and word-formation. Moscow: Rus. lang., 2000.

[20] S.A. Kuznetsov, Large explanatory dictionary of the Russian language: A-Z. RAS. Inst. Lingv. Research. St. Petersburg: Norint, 1998.

[21] Explanatory dictionary of the Russian language. Edited by D.V. Dmitrieva. Moscow: Astrel, AST, 2003.

[22] A.N. Azrilian (ed.), Large accounting dictionary. Moscow: Instit. of the New Econ., 2015.

[23] A.N. Azrilyan (ed.), A large economic dictionary. Moscow: Instit. of the New Econ., 2004
[24] I.M. Kulikov (ed.), The global economy. Encyclopedia. Moscow: Finance and Statistics, 2011.

[25] T.F. Efremova, The modern explanatory dictionary of the Russian language. Vol. 2. Moscow: AST, Astrel, Harvest, Lingua, 2006.

[26] F.A. Brockhaus, I.A. Efron, Encyclopedic Dictionary, ed. by I.E. Andreevskiy. Vol. 38. St. Petersburg: Censorship Committee - Man, 1903.

[27] V.F. Gorshenin, "The human resource value in modern economy", Kazan Sci. J., no. 4, pp. 42-45, 2010.

[28] O.E. Pirogova, V.A. Plotnikov, "What is the object of management in the economy: cost or value? to the question of the domestic interpretation of the concept "Value based management"', J. "Izv. St. Peterburgskogo gos. Ekon. Univer.”, vol. 6, no. 108, pp. 13-18., 2017.

[29] R.A. Vanyukova, "Accouting of lossed of the rejects in agricultural production”, Busin. Ed. Law, vol. 4, no. 49, pp. 259-263, 2019.

[30] A.A. Ezhevsky, N.V. Krasnoshchekov, "Losses in agriculture and ways of their elimination", Machinery and Equipment for Rural Area, no. 12 pp. 8-12, 2010

[31] E.V. Ryabukhina, M.V. Nuzhdina, "Meaning of the after harvesting grain process", Azimuth of sci. res.: econ. and administrat., vol. 1, no. 10 , pp. $112-113,2015$

[32] P. Demir, S. Yayla, O. Aksoy, I. Özaydin, "Financial losses from foot diseases in cattle farms in Kars Province", Turkish J. of Veter. and Animal Sci., vol. 37, no. 1, pp. 20-25, 2013.

[33] F. Tatlidil, T. Kiral, E. Gündoğmuş, H. Fidan, "The Effect of Crop Losses during Pre-Harvest and Harvest Periods on Production Costs in Tomato Production in the Ayaş and Nallıhan Districts of Ankara Province", Turkish J. of Agricult. and Forestry, vol. 29, no. 6, pp. 499-509, 2005.

[34] I.A. Kondakova, V.I. Levin, I.P. Lgova, Yu.V. Lomova, E.A. Vologzhanina, Antoshina O.A. "Mycotoxins of the Grain Mass Are an Important Problem of Agricultural Enterprises", Int. J. of Advan. Biotechnol. and Res., vol. 10, iss. 2, pp. 223-230, 2019.

[35] N.V. Byshov, I.A. Uspenskiy, I.A. Yukhin, N.V. Limarenko, "Ecological and technological criteria for the efficient utilization of liquid manure", IOP Conf. Ser. Earth and Environmental Sci., vol. 422, no. 1,2020

[36] R.H. Beach, Y.W. Zhang, B.A. Mccarl, "Modeling bioenergy, land use, and ghg emissions with fasomghg: model overview and analysis of storage cost implications", Climate Change Econ., spec. iss. on "The Econ. of Biofuels", vol. 03, no. 03, 2012.

[37] A.C.K. Klinger, D.B.S. Sartori, D.B. Falcone, G.S.P de Toledo, L.P. da Silva, "Viabilidade econômica de baraço de batata-doce em dietas para coelhos", Custos e @ gronegócio on line, vol. 15, no. 4, pp. 370-388, Out-Dez 2019.

[38] M.H. Siddiqui, M.A. Iqbal, W. Naeem, I. Hussain, A. Khaliq, "Bioeconomic viability of rainfed wheat (Triticum aestivum L.) cultivars under integrated fertilization regimes in Pakistan", Custos e @ gronegócio on line, vol. 15, no. 3, pp. 81-96, Jul-Set 2019.

[39] E.P. Polikarpova, I.E. Mizikovskiy, "Preparing accounting information on costs for manufactured crop production”, Custos e @ gronegócio on line, vol. 14, no. 4, pp. 149-165, 2018

[40] O.V. Lesnyh, "Recording of losses caused by defective goods at a dairy", Dairy Industry, no. 5, pp. 16-17, 2011

[41] M.A. Rudakova, A.R. Davydov, E.A. Tretyakova, "Optimisation of cos structure of industrial enterprise for output products quality assurance", Perm univer. herald. Econ., vol. 3, no. 18, pp. 48-54, 2013.

[42] I.E. Mizikovskiy, E.P. Polikarpova, "Structuring the information field of production costs in order to form the prime cost of dairy cattle", Bull. for Professional Accountants, no 3,pp. 20-28, 2019. 